\title{
LOGIKA ORKESTRASI PADA RANGKAIAN KOMUNIKASI PEMASARAN TERPADU MELALUI LIFEBUOY BERBAGI SEHAT
}

\author{
Catherine $^{1}$, Destyana Wahyu Mulyadi ${ }^{2}$ dan Nyken Ayu Phinesa ${ }^{3}$ \\ Universitas Bunda Mulia \\ Email: catherinecate22@gmail.com
}

\begin{abstract}
ABSTRAK
Komunikasi dan pemasaran saling berkaitan dan memiliki hubungan erat. Proses komunikasi pemasaran terintegrasi (IMC) menciptakan hubungan positif dengan konsumen dan stakeholder membawa keuntungan melalui penyampaian pesan atau strategi yang direncanakan secara matang dengan tujuan berinteraksi dengan konsumen. Penelitian ini bertujuan untuk mengetahui bagaimana sistem komunikasi pemasaran Lifebouy yang terintegrasi dalam orkestrasi dan channel apa saja yang digunakan Lifebouy dalam kegiatan pemasarannya. Penelitian ini menggunakan pendekatan kualitatif dengan tradisi sosiokultural dan metode interaksi simbolik. Lifebuoy memiliki beragam kegiatan pemasaran yang berfokus pada kesehatan salah satunya adalah Lifebuoy Berbagi Sehat. Meskipun memiliki banyak kategori dan varian produk, tetapi Lifebuoy selalu berkomitmen menjaga kesehatan dan kebersihan pengguna melalui produkproduknya. Kampanye Lifebuoy Berbagi Sehat menanamkan kebiasaan baik dan menginspirasi masyarakat untuk melakukan langkah kecil setiap harinya, yang bila digabungkan mampu mewujudkan perubahan besar bagi dunia. Gerakan moral dan aksi nyata yang digulirkan berdampak positif untuk kesehatan masyarakat luas. Lifebuoy menanam citra dirinya sebagai perusahaan yang peduli terhadap problema di tengah-tengah masyarakat bukan hanya mempromosikan produknya tetapi turut berperan membantu mengatasi masalah sosial di Indonesia.
\end{abstract}

Kata Kunci: Komunikasi Pemasaran Terintegrasi, Orchestration, Sosiokultural, Interaksi Simbolik, Lifebuoy

\section{LOGIC OF ORCESTRATION ON INTEGRATED MARKETING COMMUNICATION CONCATENATION THROUGH LIFEBUOY'S HEALTHY SHARING}

\begin{abstract}
Communication and marketing are interrelated and have a close relationship. The integrated marketing communication process (IMC) creates positive relationships with consumers and stakeholders bring benefits through the delivery of messages or strategies that are planned carefully with the aim of interacting with consumers. This study aims to find out how Lifebouy's marketing communication system is integrated in orchestration and what channels Lifebouy uses in its marketing activities. This research uses a qualitative approach with sociocultural traditions and symbolic interaction methods.. Lifebuoy has a variety of marketing activities that focus on health, one of which is Lifebuoy Shares Healthy. Despite having many product categories and variants, Lifebuoy is always committed to maintaining the health and hygiene of users through its products. The Lifebuoy Sharing Healthy Campaign instills good habits and inspires people to take small steps every day, which when combined can bring about great changes for the world. Moral movements and concrete actions that are rolled out have a positive impact on public health at large. Lifebuoy has planted its image as a company that cares about problems in the community, not only promoting its products but also contributing to helping overcome social problems in Indonesia.
\end{abstract}

Keywords: Intergrated Marketing Communication, Orchestration, Sosiocultural, Symbolic Interaction, Lifebuoy 
Korespondensi: Catherine. Universitas Bunda Mulia. Jakarta No. HP, WhatsApp: 087883570195 Email: catherinecate22@gmail.com

\section{PENDAHULUAN}

Komunikasi pemasaran salah satu hal yang penting bagi suatu perusahaan untuk membantu kegiatan pemasaran. Komunikasi akan dapat bekerja dengan baik ketika acara datang saling pengertian, yaitu, jika kedua pihak, pengirim dan penerima dapat memahami informasi. Ini artinya dapat disimpulkan bahwa komunikasi dalam dunia sosial media on line hanya bisa disebut komunikasi jika pihak yang menyampaikan informasi memiliki pengertian, atau paling tidak saling mengerti, baik yang menyampaikan informasi maupun yang menerima informasi (Mahayoni, 2015: 3).

Pemasaran sebagai upaya memperkenalkan perusahaan kepada masyarakat luas sehingga membutuhkan strategi pemasaran yang tepat dan tepat sasaran (Tuhuteru \& Sukmawati, 2019: 63). Pemasaran dengan komunikasi merupakan hubungan yang erat. Komunikasi sebagai proses pengoperan lambang-lambang yang diartikan sama antara individu kepada individu, individu kepada kelompok, kelompok kepada kelompok, dan kelompok kepada massa. Komunikasi dalam kegiatan pemasaran bersifat kompleks, artinya tidak sesederhana seperti ketika kita berbincangbincang dengan rekan sekantor, atau dengan keluarga di rumah (Lestari, 2015: 141).

Komunikasi pemasaran sebagai salah satu bagian dari strategi pemasaran untuk mendapatkan pelanggan, baik yang baru maupun yang lama agar pelanggan tertarik dan membeli produk tersebut. Sstrategi pemasaran menggambarkan ekspektasi perusahaan akan dampak dari kegiatan pemasaran terhadap permintaan produk di pasaran tertentu (Tarsani, 2016: 57).

Bentuk komunikasi ini mendorong penyampaian pesan yang dilakukan melalui sejumlah strategi komunikasi yang canggih, setelah melewati proses perencanaan yang matang. Komunikasi dipengaruhi oleh berbagai bentuk media yang digunakan, daya tarik pesan, frekuensi penyajian dan dalam hal penyampaian pesan-pesan komunikasi yang dihadapkan pada berbagai persoalan, seperti: perbedaan persepsi, perbedaan budaya, dan keterbatasan media yang digunakan.

Komunikasi pemasaran dapat dinyatakan sebagai kegiatan komunikasi yang ditujukan untuk menyampaikan pesan kepada konsumen dan pelanggan dengan menggunakan sejumlah media dan berbagai saluran yang dapat dipergunakan dengan harapan terjadinya tiga tahap perubahan, yaitu: perubahan pengetahuan, perubahan sikap, dan perubahan tindakan yang dikehendaki. Adapun jenis media yang dapat digunakan seperti: folder, poster, banners, fliers, televisi, radio, majalah, dan surat kabar (Bani et al., 2001: 14).

Promosi akan menggambarkan mekanisme pembentukan dan penerapan strategi. Akan tetapi tidak semua media dapat dijadikan sebagai alat mempromosikan diri. Media promosi dapat dibagi menjadi dua, menggunakan advertising (pengiklanan), publikasi dan media debat/pengumpulan massa (Suherman, 2019: 13). 
Menurut Duncan (2002), Integrated Marketing Communication (IMC) merupakan proses yang lintasfungsional dalam menciptakan dan mendukung hubungan yang menguntungkan secara kapital dengan pelanggan dan para stakeholder lainnya melalui pengendalian yang strategis atau teknik mempengaruhi semua pesan yang dikirimkan kepada kelompok konsumen dan memperkuat data, yang memiliki tujuan utama untuk berdialog dengan konsumen. Proses lintasfungsional artinya bahwa semua departemen dalam perusahaan dan agensi sebagai pihak luar perusahaan harus bekerja sama secara harmonis melalui tahap perencanaan dan pengawasan brand relationship. Dengan menciptakan dan mendukung hubungan dengan para stakeholder, pelanggan menjadi fokus perhatian yang kemudian menciptakan interaksi dan memuaskan kebutuhan dan keinginannya. Lebih lanjut, pengawasan strategis atau pengaruh semua pesan yang dimaksudkannya merujuk pada semua aspek-aspek marketing mix. Sedangkan, pemikirannya tentang memperkuat tujuan dialog mengidentifikasikan bahwa konsumen pada dasarnya sudah lelah menjadi objek komunikasi dan ingin mendapatkan kesempatan untuk berinteraksi (Krypton et al., 2018: 43).

\section{Integrated Marketing Communication (IMC)} diartikan sebagai proses untuk merencanakan, melaksanakan, dan memantau pesan brand yang menciptakan hubungan pelanggan. IMC menjadi sebuah proses untuk merencanakan, melaksanakan, memantau dan mengevaluasi pesan-pesan merek yang menciptakan kesetaraan hubungan jangka panjang yang saling menguntungkan antara konsumen dengan merek yang ditawarkan (Huda, 2014: 2).

Ada beberapa faktor yang mempengaruhi perkembangan konsep dari IMC, yaitu: perubahan pada pasar konsumen dan perubahan pada pasar bisnis. Perubahan pasar konsumen ditandai disebabkan oleh luapan informasi yang timbul akibat meningkatnya jumlah pesan-pesan komersial. Iklan di media massa mulai mengalami penurunan dalam menarik perhatian dari konsumen. Perubahan pada pasar bisnis menyebabkan terjadinya proses merger, akusisi, dan perubahan struktur organisasi dan manajemen pada perusahaanperusahaan. Ketertarikan pihak manajemen perusahaan terhadap hasil jangka pendek, sehingga meningkatkan pemahaman akan pentingnya strategi komunikasi serta meningkatnya pemahaman akan pentingnya komunikasi internal perusahaan yang baik (Ulfa \& Marta, 2016: 74).

Orkestrasi menggunakan berbagai platform dan saluran untuk memusatkan perhatian pada objek yang konsisten dan gigih dalam pesan. Orkestrasi mengacu pada upaya untuk mencapai kesuksesan dengan menemukan dan mengelola kombinasi kreatif untuk nilai; itu adalah kunci untuk melaksanakan manajemen hubungan baik cara lama maupun baru dalam menyelesaikan sesuatu (Pfefferman et al., 2013: 439).

Orkestasi kampanye diwujudkan ketika tim berkolaborasi untuk menyatukan data dan pesan pelanggan. Setelah tim dan teknologi Anda bekerja bersama, Anda dapat menggunakan seluruh pandangan pelanggan untuk menyampaikan pesan yang relevan dan personal. 
Pengalaman yang diatur Anda akan melengkapi kebutuhan, keinginan, dan keinginan pelanggan Anda di saluran yang tepat, pada waktu terbaik, dan dengan frekuensi yang diinginkan.

Unilever merupakan perusahaan Indonesia yang bergerak di bidang Home and Personal Care serta Foods and Ice Cream. Unilever Indonesia bediri pada 5 Desember 1933 dengan nama Lever Zeepfabrieken N.V dan pada 30 Juni 1990 nama perusahaan diubah menjadi PT Unilever Indonesia Tbk (Unilever, 2020).

Unilever menerapkan standar berperilaku yang ditetapkan perusahaan ketika berhubungan dengan mitra bisnis, masyarakat dan lingkungan sekitar. Unilever selalu bekerja dengan integritas dan rasa hormat terhadap semua yang terlibat dalam bisnis, memberikan dampak positif kepada masyarakat melalui brand dan kegiatan-kegiatan yang diadakan, menetapkan tujuan untuk keberhasilan dimasa yang akan datang, serta bekerja sama dengan pemasok yang memiliki Kode Etik selaras dengan prinsip yang dianut oleh Unilever.

Unilever memiliki tujuan mulia yakni menciptakan kehidupan yang ramah lingkungan dan memberikan manfaat sosial kepada masyarakat. Masing-masing ikon pada logo mencerminkan suatu aspek dari setiap upaya serta tujuan Unilever. Beberapa ikon-ikonnya yaitu es krim (kesenangan dan kenikmatan), tangan (kepekaan dan kepedulian untuk membantu masyarakat), partikel (merujuk pada ilmu pengetahuan dan komitmen untuk meningkatkan kehidupan konsumen Unilever), kemasan (dedikasi terhadap pengalaman konsumen), transformasi (perubahan yang positif), gelombang (kebersihan, kesegaran dan kekuatan), kelapa sawit (lingkungan), siklus kebajikan (mengurangi limbah yang berhubungan dengan pembuangan Unilever) serta matahari (sumber energi dalam menciptakan cara inovatif untuk mengurangi gas rumah kaca).

Fokus strategi Unilever yaitu untuk membangun strategi untuk menjadikan kehidupan berkelanjutan yang lumrah serta mewujudkan visi yang menghasilkan kemajuan yang memberi keuntungan pada semua pemangku kepentingan. Visi dari Unilever yaitu mengembangkan bisnis, meningkatkan kesehatan dan kesejahteraan, meningkatkan penghidupan, dan mengurangi dampak lingkungan.

Lifebuoy merupakan salah satu brand dari Unilever, yang bergerak di bidang personal care. Lifebuoy pertama kali dibentuk oleh William Lever dengan tujuan untuk menghentikan Kolera di Inggris. Sabun Lifebuoy mengandung bahan yang dipatenkan Lifebuoy yaitu ActivSilver Formula yang mampu melindungi kulit dari kuman. Lifebuoy menawarkan solusi untuk kebersihan dan kesehatan yang terjangkau dan mudah ditemui sehingga orang tidak lagi merasa khawatir terhadap kebersihan dan akibatnya buruknya. Hal yang utama bagi Lifebuoy yakni janji perlindungan dan komitmennya untuk mendukung kehidupan melalui perlindungan yang lebih baik. Lifebuoy memiliki beberapa kategori produk yaitu sabun batang, sabun cair, sabun cuci tangan, hand sanitizer dan sampo (Lifebuoy, 2020). 
Lifebuoy selalu berupaya untuk meminimalisir limbah kami mulai dari hulu, tengah, sampai hilir dari rantai bisnisnya. Upaya ini sejalan dengan strategi Unilever Sustainable Living Plan. Ekonomi sirkular merupakan pendekatan yang sedang Lifebuoy jalankan di mana Lifebuoy mengelola semua bahan dan limbah pada setiap siklus bisnisnya secara bertanggung jawab seraya mengurangi dampak lingkungan yang dihasilkan dari dalam operasi bisnis Lifebuoy.

George Herbert Mead menyatakan bahwa orang bertindak berdasarkan makna simbolik yang muncul di dalam situasi tertentu. Teori interaksi simbolik menekankan pada hubungan antara simbol dan interaksi. Ralph Larossa dan Donald C. Reitzes (1993) mengatakan bahwa interaksi simbolik adalah sebuah kerangka referensi untuk memahami bagaimana manusia, bersama dengan orang lainnya, menciptakan dunia simbolik dan bagaimana dunia ini, sebaliknya, membentuk perilaku manusia (West \& Turner in Raga et al., 2017: 1046).

Komunikasi massa dapat dijelaskan dari dua cara pandang, yakni bagaimana orang memproduksi pesan dan menyebarkannya melalui media, dan bagaimana orang-orang mencari serta menggunakan pesan-pesan tersebut di pihak lainnya. Secara sederhana, komunikasi massa dapat diartikan sebagai proses komunikasi melalui media massa. Faktor media massa sangat dominan dalam studi komunikasi massa. Pengkajian komunikasi massa banyak dipengaruhi oleh dinamika media massa dan penggunaannya oleh khalayak. Perkembangan media massa sendiri banyak dikaitkan dengan sejumlah faktor yang melingkupinya, misalnya jumlah melek huruf yang semakin besar, perkembangan pesat dalam bidang ekonomi, kemajuan teknologi informasi dan komunikasi, fenomena urbanisasi, dan faktor iklan (Halik, 2013: 2).

Rumusan masalah dalam penelitian ini adalah (1) Bagaimana sistem komunikasi pemasaran Lifebouy yang terintegrasi berdasarkan terminologi orkestrasi? (2) Channel apa saja yang digunakan Lifebouy dalam kegiatan pemasaran produknya? Sedangkan tujuan penelitiannya adalah (1) Untuk mengetahui bagaimana sistem komunikasi pemasaran lifebouy yang terintegrasi berdasarkan terminologi orkestrasi dan (2) Untuk mengetahui channel apa saja yang digunakan Lifebouy dalam kegiatan pemasaran produknya.

\section{METODE PENELITIAN}

Penelitian ini mengunakan metode penelitian kualitatif. Penelitian kualitatif berupa metode penelitian yang mendeskripsikan dan menganalisis fenomena yang diamati, mengacu pada data non numerik. Penelitian kualitatif merupakan suatu penelitiaan yang bermaksud memahami fenomena tentang apa yang dialami oleh subjek penellitian misalnya perillaku, pengaruh sosial, persepsi, motivasi, tindakan secara holistik dan dengan cara deskripsi dalam bentuk kata-kata dan bahasa pada suatu konteks khusus yang alamiah serta dengan memanfaatkan berbagai metode alamiah yang tidak bisa diuji oleh kuantitatif.

Penelitian kualitatif menurut Holloway (2008: 7) memilki karakteristik yaitu (1) Berfokus pada kata, (2) Menuntun keterlibatan peneliti 
(partisipatif), (3) Dipengaruhi sudut pandang partisipan (orang yang menjadi sumber data), (4) Fokus penelitian yang holistik, (5) Desain dan penelitiannya bersifat fleksibel, (6) Lebih mengutamakan proses daripada hasilnya, (7) menggunakan latar alami, dan (8) Menggunakan analisis induktif baru deduktif.

Tujuan utama melakukan coding dalam penelitian kualitatif ialah untuk membentuk kategori-kategori utama berdasarkan berbagai sumber data yang telah dikumpulkan peneliti. Dalam konteks ini, segmen-segmen informasi yang berasal dari berbagai sumber data dapat membentuk kategori-kategori. Selanjutnya, peneliti kualitatif dan dapat menghubungkan kategori yang satu dengan yang lain setelah melakukan coding. Dalam penelitian kualitatif, terutama dengan menggunakan desain grounded theory, peneliti dapat membentuk konsep-konsep teoritis yang baru berdasarkan kategori kategori yang dibentuk melalui proses coding. Coding juga bertujuan mengumpulkan semua informasi yang relevan dari berbagai sumber yang relevan berkaitan dengan suatu kasus tertentu. Terdapat tiga jenis coding dalam penelitian kualitatif, yakni sebagai berikut: (1) Coding deskriptif merupakan salah satu jenis coding dalam penelitian kualitatif untuk menyimpan informasi masing-masing variabel agar dapat diidentifikasi dalam analisis. Coding deskriptif dapat diasosiasikan dengan coding bebas. (2) Coding tematik merupakan pemberian label terhadap teks berdasarkan topictopik yang diteliti dalam penelitian. Dengan kata lain peneliti menempatkan informasi-informasi dalam teks merupakan berdasarkan topik-topik utama. Ini hanya untuk mengkategorikan informasi-informasi ke dalam teks tema-tema utama bukan untuk menginterpretasi data. Dalam tahap ini peneliti dapat memahami tentang apa yang terdapat dalam bagian-bagian teks sehingga menghasilkan topik-topik utama penelitian. (3) Coding analitik memberikan interpretasi secara lebih mendalam terhadap informasi-informasi yang terdapat dalam dokumen. Dalam proses coding manual, peneliti perlu menyediakan folderfolder untuk masing-masing kategori atau topik. Kata kategori di simpan dalam node system, misalnya node kesadaran orang tua merupakan semua informasi yang berkaitan dengan kesadaran orang tua dalam memotivasi anak untuk belajar menyadari pentingnya sekolah dan lain-lain. Dengan demikian, coding analitis berkaitan dengan bagaimana peneliti meminta menginterpretasi dan merefleksikan utama dari topik-topik utama yang telah di kategorikan (Bandur, 2019: 194-195).

Pendekatan sosiokultural menunjukkan cara pemahaman kita terhadap makna, norma, peran dan peraturan yang dilakukan dalam komunikasi. Teori ini menjelaskan bahwa realitas bukanlah seperangkat susunan di luar kita, tetapi dibentuk melalui proses interaksi dalam kelompok, komunitas dan budaya. Gagasan utama dari tradisi sosiokultural memfokuskan diri pada bentukbentuk interaksi antar manusia daripada karakteristik individu atau model mental. Tradisi sosiokultural terkait dengan individu dan interaksinya dengan kelompok lain yang dimana dalam kelompok tersebut terdapat beragam perbedaan tetapi dalam cakupan yang tersusun 
secara sosial (luas, menyeluruh) dan bukan secara psikologis atau individu masing-masing. Tradisi sosiokultural lebih terfokus pada pola-pola interaksi antar manusia daripada hal-hal yang terkait dengan sifat yang dimiliki seorang individu. Tradisi ini cenderung tertarik pada bagaimana makna diciptakan dalam interaksi sosial. Makna dan kata-kata dalam situasi sosial yang sesungguhnya menjadi sangat penting. Simbol dan makna yang dinilai penting bagi kelompok sosial dan budaya tertentu mampu memikat para peneliti dari tradisi sosiokultural pada umumnya, walaupun tidak selalu, bersifat menyeluruh (holistic) (Morissan, 2013: 38-39).

Sudut pandang yang berpengaruh di dalam tradisi sosiolinguistik, yaitu (1) Paham interaksi simbiolis, menekankan pentingnya observasi partisipan dalam kajian komunikasi sebagai cara dalam mengeksplorasi hubungan-hubungan sosial. Ide dari paham interaksi simbolik telah diadopsi dan ditekuni oleh pakar sosial serta sekarang dimasukkan dalam kajian kelompok, emosi, diri, politik dan struktur sosial. (2) Konstruktivisme sosial, bagaimana pengetahuan manusia dibentuk melalui interaksi sosial. Identitas benda dihasilkan dari bagaimana kita berbicara tentang objek, bahasa yang digunakan untuk menangkap konsep kita dan cara-cara kelompok sosial menyesuaikan diri pada pengalaman umum mereka. (3) Sosiolinguistik, manusia menggunakan bahasa secara berbeda-beda dalam kelompok budaya dan kelompok sosial yang berbeda-beda.

Metode dalam tradisi sosiokultural yang digunakan adalah metode interaksi simbolis dan pengembangan diri. Metode ini menekankan dan berfokus pada hakikat manusia sebagaimakhluk relasional. Interaksi simbolik dipengaruhi olehstruktur sosial yang membentuk atau menyebabkan perilaku tertentu, yang kemudian membentuk simbolisasi dalam interaksi sosial masyarakat. Interaksi simbolik menuntut setiap individu mesti proaktif, refleksif dan kreatif, menafsirkan, menampilkan perilaku yang unik, rumit, dan sulit diinterpretasikan. Interaksi simbolik menekankan dua hal, yaitu: (1) Manusia dalam masyarakat tidak pernah lepas dari interaksi sosial. (2) Interaksi dalam masyarakat mewujud dalam simbol-simbol tertentu yang sifatnya cenderung dinamis (Ahmadi, 2008: 311).

Makna-makna yang ada dalam interaksi ini merupakan sesuatu yang dijadikan dan telah disepakati menjadi suatu simbol. Simbol tersebut akhirnya diperkenalkan kepada orang lain dan disepakati menjadi suatu kesepakatan bersama. Pada interaksi simbolik, perilaku manusia merupakan proses dimana manusia dapat mengatur tindakan mereka dan menyesuaikannya dengan orang lain yang berinteraksi dengan mereka. Pada interaksi simbolik individu merespon berbagai objek baik objek fisik maupun sosial. Lalu makna yang diinterpretasikan selalu dapat berubah-ubah sesuai dengan keadaan saat interaksi sosial. Penggunaan simbol komunikasi akan dilihat oleh sistem yang berada disekelilingnya, sebab nilai atau norma masyarakat sebuah standar dalam perlakuan anggota masyarakat yang berfungsi untuk menjaga kestabilan interaksi internal anggota masyarakat (Hutapea, 2016: 1). 
Tiga tema konsep pemikiran George Herbert Mead yang mendasari interaksi simbolik antara lain: (1) Pentingnya makna bagi perilaku manusia, (2) Pentingnya konsep mengenai diri dan (3) Hubungan antara individu dengan masyarakat. Sedangkan Herbet Blumer (1969), berasumsi: (1) Manusia bertindak terhadap manusia lainnya berdasarkan makna yang diberikan orang lain pada mereka, (2) Makna diciptakan dalam interaksi antarmanusia dan (3) Makna dimodifikasi melalui proses interpretif. Tema kedua pada interaksi simbolik berfokus pada pentingnya "Konsep diri" atau "Self-Concept". Dimana, pada tema interaksi simbolik ini menekankan pada pengembangan konsep diri melalui individu tersebut secara aktif, didasarkan pada interaksi sosial dengan orang lainnya. Tema ini memiliki dua asumsi tambahan, menurut a Rossan \& Reitzes (1993) dalam West-Turner (2008: 101), antara lain: (1) Individu-individu mengembangkan konsep diri melalui interaksi dengan orang lain. (2) Konsep diri membentuk motif yang penting untuk perilaku (Siregar, 2016: 104).

McQuails mengatakan bahwa "the entire study of mass communication is based on the premise that the media have significant effects". Ini menandakan bahwa memang media memberikan dampak yang nyata pada khalayak (Widoawati, 2012: 76). Gerbner mendefinisikan komunikasi massa sebagai produksi dan distribusi yang berlandaskan teknologi dan lembaga dari arus pesan yang kontinyu serta paling luas yang dimiliki orang dalam masyarakat industri. Sistem komunikasi massa mensyaratkan perangkat teknologi yang mendukung proses produksi, reproduksi, dan pemasaran media massa. Proses kerja media massa berlangsung terus-menerus secara kontinyu sehingga memiliki periodisasi tertentu dalam program atau produknya yang melayani kebutuhan akan informasi dan hiburan khalayaknya. Media massa merupakan sarana penyampaian komunikasi dan informasi yang melakukan penyebaran informasi secara masal dan dapat di akses oleh masyarakat secara luas pula (Kholik, 2015: 4).

Komunikasi dalam konteks massa, atau lazim dikenal dengan komunikasi massa, telah banyak didefinisikan akademisi. Diantaranya dikemukakan Bittner, bahwa komunikasi massa yaitu pesan yang dikomunikasikan melalui media massa pada sejumlah besar orang (Mass communication is messages communicated through a mass medium to a large number of people). Definisi ini menyiratkan makna bahwa komunikasi massa pada hakikatnya adalah sebuah proses komunikasi yang dilakukan oleh suatu organisasi media massa kepada khalayak luas yang anonim. Littlejohn menyebut proses komunikasi yang demikian dengan konsep media encoding, yaitu proses dimana organisasi media memediakan pesannya kepada khalayak (Imran, 2013: 48)

Komunikasi massa memiliki beberapa karakteristik yaitu (1) Adanya komunikator yang terlembagakan, hal ini dimaksudkan bahwa komunikator dalam komunikasi massa adalah suatu lembaga atau organisasi. (2) Pesan yang disampaikan bersifat umum, hal ini dikarenakan komunikasi massa memiliki khalayak yang luas 
jangkauannya dan juga bersifat terbuka. (3) Komunikannya anonim dan heterogen, dengan adanya media massa sebagai salurannya, komunikasi massa tidak berlangsung secara tatap muka. Lalu, komunikan dan komunikator pada komunikasi massa tidak saling mengenal dan juga tidak mengetahui usia, jenis kelamin, latar belakang dan lain-lain. (4) Media massa menimbulkan keseragaman, dengan kekuatan penyebaran pesan yang dapat menjangkau secara luas, pesan yang dapat diterima secara serentak oleh khalayak. (5) Umpan balik tidak langsung, hal ini tentunya dikarenakan komunikasi massa terjadi secara tidak tatap muka sehingga komunikan tidak dapat secara langsung memberikan umpan balik. (6) Bersifat satu arah, tidak adanya dialog yang terjadi antara pihak komunikator dan komunikan. (7) Mementingkan isi pesan dibandingkan hubungan, hal ini dikarenakan komunikan dan komunikator tidak saling mengenal satu sama lain sehingga yang diutamakan adalah kejelasan dari pesan yang disampaikan.

\section{HASIL DAN PEMBAHASAN}

Hasil dan pembahasan mempunyai sifat objektif dan subjektif. Hasil dan pembahasan sebagai pertimbangan atau acuan yang mendasar untuk dijadikan sebagai hasil analisis dari teori interaksi simbolik. Untuk meningkatkan kualitas dalam strategi komunikasi pemasaran suatu produk dibutuhkan sebuah strategi pemasaran yang efektif dan kuat. Kegiatan pemasaran dan kampanye Lifebuoy menciptakan interaksi dan citra positif dibenak masyarakat. Teknik pemasaran yang beragam dan konsisten membuat Lifebuoy tetap eksis dan dikenal oleh masyarakat luas sampai saat ini.

\section{Dirijen}

Di dalam orkestra, satu dirijen berarti satu nada komando dan tujuan bersama, tidak ada pemimpin ganda dalam sebuah orkestra. Demikian juga di dalam kampanye IMC yang menggunakan satu tujuan bersama, yang mempunyai satu visi misi demi melancarkan agar tercapainya tujuan bersama.

Lifebuoy mempunyai beberapa kategori produk, yaitu sabun cuci tangan, sabun mandi, hand sanitizer, dan sampo. Masing-masing produk mempunyai manfaat yang sama yaitu membersihkan dan mengurangi kuman yang ada di kulit, tangan badan maupun kulit kepala. Masing-masing produk tersebut memiliki ciri khas warna dominan putih dan dengan stiker kemasan bergambar keluarga (orang tua dan anak) di setiap produknya, hal tersebut merupakan salah satu cara agar pelanggan dapat dengan mudah mengenali produk Lifebuoy.

Lifebouy mempunyai berbagai varian dari produknya, yaitu Mild Care Body Wash dengan botol berwarna biru, Cool Fresh Body Wash dengan botol berwarna hijau dan Lemon Fresh Body Wash yang berwarna kuning. Dengan warna-warna ini, dipercaya memiliki suatu sifat dan karakter tersendiri lalu membantu membuat konsumen tertarik untuk membeli dan menggunakan produk Lifebuoy. Lifebuoy yang telah dikenal sebagai produk yang efektif dalam menghilangkan kuman di tubuh. Tentunya, memiliki peran yang cukup besar bagi para 
konsumen dalam menjaga kebersihan tubuhnya. Para orang tua dalam keluarga-keluarga tentunya memiliki kepercayaan tersendiri pada produk Lifebuoy sehingga para orang tua pun akan membeli dan menggunakan produk-produk Lifebuoy agar anak-anak mereka bersih dari kuman. Produk Lifebuoy yang sangat dekat dengan keluarga ini secara utuh hadir dengan berbagai macam produknya dari sabun cuci tangan, sabun mandi, sampo dan hand sanitizer, tentunya membuat konsumen tidak perlu mencari brand lain untuk memenuhi semua kebutuhannya, karena produk Lifebuoy telah hadir secara lengkap di tengah-tengah keluarga. Pemasaran produk Lifebuoy dilakukan melalui pemanfaatan media konvensional dan juga media baru.

\section{Harmonisasi}

Orkestra memiliki ciri khas yaitu kesatuan dan keselarasan nada dan irama. Dalam kampanye IMC, idealnya tercipta keselarasan antara komunikasi korporat dan promosi produk, dalam tujuan, strategi, pesan dan media yang digunakan. Ketika sudah mempunyai keselarasan, maka dapat menjadi acuan komunikasi bagi korporat dengan pihak luar agar tidak adanya kesalahan dalam pelaksanaannya.

Kampanye IMC dilakukan oleh Lifebuoy dimana Lifebuoy sangat banyak melakukan halhal yang sangat menyentuh antara perusahaan Lifebuoy dengan masyarakat yang menggunakan produk Lifebuoy baik sampo, sabun mandi, sabun cuci tangan maupun hand sanitizer. Hampir apapun yang dikeluarkan oleh Lifebuoy digemari bahkan diterima oleh masyarakat karena efektif membersihkan kuman dan harganya yang bersahabat serta mudah ditemui dimanapun. Itulah dampak dari adanya keharmonisasian antara Lifebouy, tujuan mulainya dan penggunanya.

Lifebuoy mengadakan kampanye "5 Tahun Bisa untuk NTT" demi mencegah penyebab kebanyakan kematian balita akibat penyakit diare dan ISPA (Infeksi Saluran Pernapasan Akut) yang dapat diatasi dengan melakukan kebiasaan yang sederhana, yakni cuci tangan pakai sabun. Pendidikan kesehatan dimulai dari bagaimana kebiasaan sehat itu dibentuk di sekolah, keluarga, atau pun lingkungan bermainnya. Salah satu budaya PHBS (Pola Hidup Bersih dan Sehat) yang penting ditanamkan sejak kecil adalah CTPS (Cuci Tangan Pakai Sabun) karena dapat mencegah lebih dari sepuluh jenis penyakit fecaloral (lewat tangan ke mulut), antara lain diare. Hal tersebut merupakan salah satu perwujudan dari misi Unilever, yaitu "Kami menginspirasi masyarakat untuk melakukan langkah kecil setiap harinya yang bila digabungkan bisa mewujudkan perubahan besar bagi dunia."

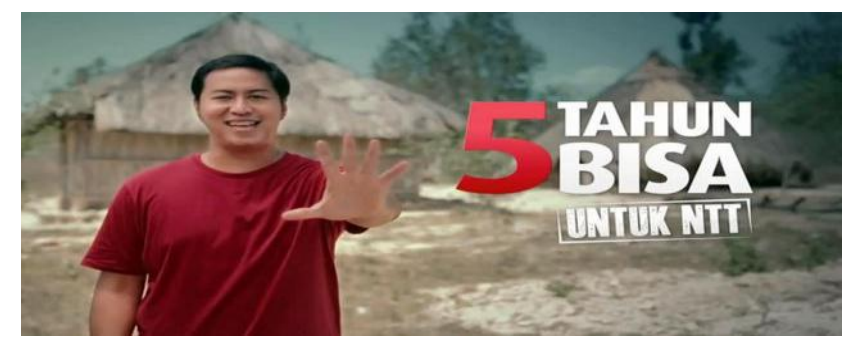

Sumber : Liputan6

\section{Gambar 1 Foto Kampanye Lifebuoy}

Kampanye ini juga masuk ke dalam teori interaksionisme simbolik, dimana Lifebuoy melakukan dan mengajarkan cuci tangan pakai sabun di dalam kegiatan "5 Tahun Bisa untuk NTT”, karena dengan itu Lifebuoy mengubah kebiasaan dan orang tua menanamkan kebiasaan 
baik kepada anaknya. Kegiatan kampanye ini Lifebuoy mengajak masyarakat untuk mendukung melalui beberapa pilihan cara yaitu dengan klik "dukung" di situs Youtube Lifebuoy untuk setiap dukungan, dan secara otomatis mereka akan memberikan donasi sebesar Rp100,- untuk program yang akan Lifebouy jalankan di desa Bitobe, NTT sebagai salah satu daerah di Kabupaten Kupang NTT, yang membutuhkan bantuan.

Program ini diluncurkan untuk membantu meningkatkan kesadaran masyarakat tentang Perilaku Hidup Bersih dan Sehat (PHBS) melalui salah satu pilarnya yaitu Cuci Tangan Pakai Sabun (CTPS) yang menurut riset telah terbukti dapat menurunkan resiko diare hingga 50\% dan ISPA (Infeksi Saluran Pernapasan Akut) hingga 45\% .

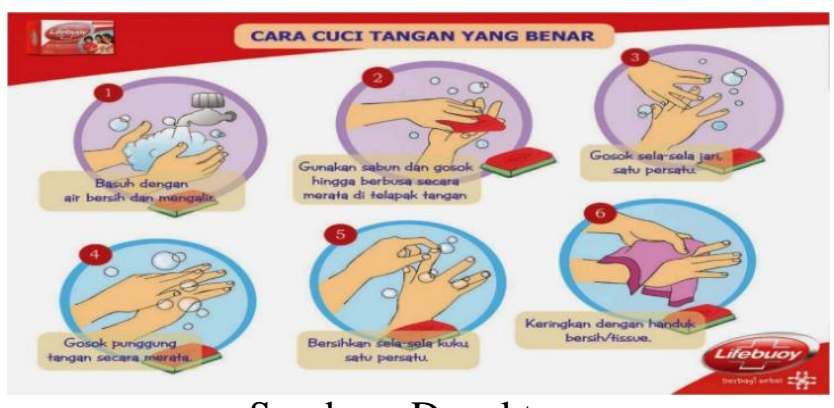

Sumber : Depoktren

\section{Gambar 2 Langkah-langkah Mencuci Tangan yang Benar versi Lifebuoy}

Kebiasaan sederhana ini mempunyai dampak yang besar terutama bagi kesehatan balita yang rentan terserang penyakit. Hal ini termasuk dalam kategori komunikasi massa dimana Lifebuoy menyampaikan pesan kepada masyarakat yang mampu menjangkau cukup banyak sehingga masyarakat akan lebih cepat mendapatkan informasi mengenai donasi yang diselenggarakan oleh Lifebuoy.

\section{Tematik}

Orkestra bisa menyajikan musik-musik klasik ataupun musik modern, namun juga dapat menyisipkan unsur-unsur dari musik etnik. Sama halnya dengan kampanye IMC yang menggunakan tema tertentu untuk menghasilkan suatu kesan dan pesan tunggal (one look, one voice), dan kemudian akan berganti tema dalam periode tertentu. Ketika merencanakan untuk membuat kampanye IMC tentunya harus ada suatu tema yang ditentukan. Dengan adanya tema dalam suatu kegiatan kampanye IMC, kegiatan menjadi lebih terarah dan memiliki fokus dan tujuan yang harus dicapai.

Pada kampanye IMC yang dilakukan oleh Lifebuoy, tentunya Lifebuoy selalu menyelaraskan kegiatan IMC-nya dengan suatu tema yang telah ditentukan. Lifebuoy sebagai pelopor kekuatan yang sangat mendukung Hari Cuci Tangan pertama di dunia, bekerja sama dengan mitra-mitranya untuk mendidik dan menginspirasi anak-anak untuk membiasakan menjaga kebersihan tangan. Untuk merayakan hari cuci tangan sedunia pada tahun 2019 silam di SDN 1 Menteng, Jakarta Pusat, Lifebuoy mengangkat tema "Antar Anak Sehat Indonesia", dengan tujuan untuk menciptakan lingkungan yang sehat bagi anak-anak dan dapat menigkuti seluruh jadwal kegiatan sekolah dengan penuh. Hal ini didasari karna Lifebuoy menyadari akan adanya ancaman-ancaman dari bakteri atau kuman penyakit yang akan menyerang anak-anak pada kegiatan seusai sekolah. Anak-anak yang sering bermain kotor-kotoran memicu datangnya penyakit apabila mereka lupa atau tidak terbiasa 
untuk mencuci tangan setelah bermain agar tidak menganggu waktu belajar di sekolah. Maka dari itu Lifebuoy senantiasa memperkuat komitmennya untuk menanamkan tentang pentingnya kebiasaan mencuci tangan pakai sabun, terutama pada anakanak.

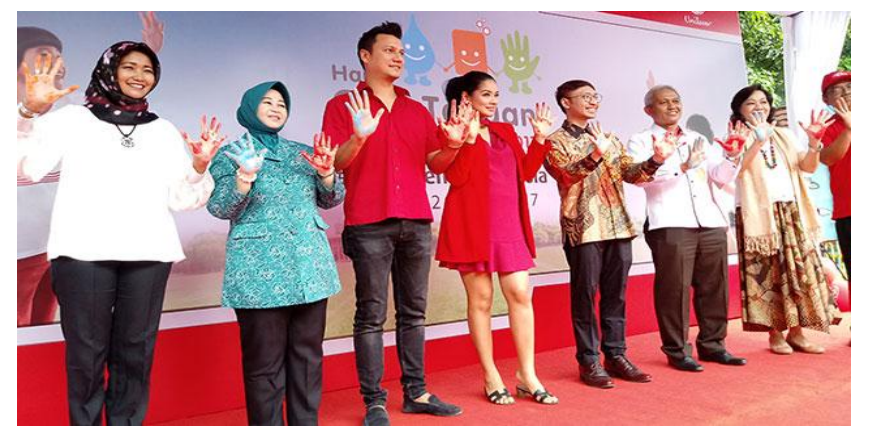

Sumber : Majalah Kartini

\section{Gambar 3 Brand Ambassador Lifebuoy}

Penanaman kebiasaan ini terkait pula dengan teori interaksionisme simbolik, dimana Lifebuoy menanamkan suatu kebiasaan pada diri seorang anak yang tentunya jika dilakukan dari masa kanak-kanak akan tertanam sampai besar nanti. Titi Kamal dan Christian Sugiono, sebagai brand ambassador dari Lifebuoy mengungkapkan pentingnya peran orang tua dalam menanamkan kebiasaan baik pada anak-anak dari sejak dini. Dan dari satu individu yang ditanamkan sejak dini kebiasaan ini akan berdampak pula bagi lingkungan sekitarnya untuk terbiasa mencuci tangan dengan sabun agar terhindar dari berbagai bakteri dan kuman penyakit.

Lifebuoy juga menyatakan bahwa edukasi cuci tangan dengan sabun yang dilakukan selama ini telah menjangkau satu milyar orang di dunia dan Lifebuoy terus menargetkan untuk mengedukasi lebih banyak lagi orang-orang di Indonesia. Kegiatan kampanye IMC Lifebuoy ini telah diteruskan selama beberapa periode dan biasanya memang diselenggarakan bertepatan dengan hari Cuci Tangan Sedunia.

Dengan adanya kampanye IMC oleh Lifebuoy tentunya disertai dengan liputan media dan adanya publikasi di media. Proses penyebaran pesan dengan media massa tentunya akan menjangkau lebih banyak target audiens dibandingkan dengan bentuk komunikasi lainnya. Komunikasi massa memiliki fungsi untuk mengedukasi, menginformasi, mempengaruhi serta menghibur. Kampanye IMC Lifebuoy ini tentunya akan menjangkau masyarakat Indonesia serta mengedukasi ratusan juta orang dan juga menginformasikan betapa pentingnya mencuci tangan dengan sabun dan juga menghibur dengan adanya kegiatan menyenangkan yang dilakukan anak-anak SDN Menteng Jakarta Pusat. Kampanye "Tangan Bersih" oleh Lifebuoy telah berkontribusi dalam tujuannya untuk mengurangi jumlah kematian anak di bawah usia lima tahun sampai dua pertiga dan juga mencegah penyakit. Pada tahun 2005, Lifebuoy dianugerahi sebuah penghargaan bernama "Citizen Brand" di Indonesia sebagai pengakuan atas semua kontribusi Lifebuoy dalam pendidikan kesehatan yang sudah bertahun-tahun dilakukan, termasuk proyek-proyek kesehatan masyarakat yang bekerjasama dengan UNICEF dan Ikatan Dokter Indonesia (IDI).

\section{Berirama}

Tempo dalam musik orkestra terkadang tidaklah monoton melainkan selalu berubah-ubah, terkadang melambat dan terkadang berubah cepat, lalu lembut maupun keras. Hal ini sama dengan 
apa yang dilakukan oleh kampanye korporat atau kampanye IMC. IMC dilaksanakan untuk membangun citra dari perusahaan, namun pada kesempatan lainnya juga dapat berbentuk promosi yang dapat mendongkrak penjualan.

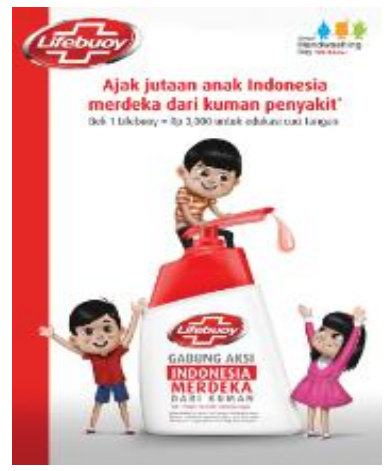

Sumber : Lokadata

\section{Gambar 4 Poster Kemasan Khusus Lifebuoy}

Kampanye IMC yang dilakukan oleh Lifebuoy pada tahun 2018 yaitu dengan meluncurkan produk Lifebuoy dengan kemasan khusus yang bertuliskan "Gabung Aksi Indonesia Merdeka dari Kuman" pada periode OktoberDesember 2018. Pada kampanye IMC Lifebuoy pada tahun 2018 ini bertujuan khusus untuk mengedukasi dan perbaikan sarana CTPS (Cuci Tangan Pakai Sabun) di banyak sekolah dasar yang masih sangat terbatas. Program ini dilaksanakan dengan cara yaitu tiga ribu rupiah dari setiap pembelian kemasan khusus Lifebuoy akan didonasikan untuk kegiatan edukasi mecuci tangan anak.

Dengan hal ini tentunya mendorong masyarakat untuk membantu berdonasi hanya dengan membeli suatu produk yang memang dibutuhkan. Tentunya kampanye IMC Lifebuoy terkait dengan aspek berirama dimana selain dapat membangun citra positif pada brand Lifebuoy mengenai donasi yang akan diberikan pada sekolah-sekolah demi menjaga anak-anak di Indonesia terbebas dari kuman penyakit, namun juga sebagai sarana promosi dan meningkatkan penjualan, karena dengan kampanye IMC yang dilakukan Lifebuoy ini, masyarakat akan terdorong untuk membeli produk Lifebuoy karna adanya rasa kemanusiaan dalam diri seseorang untuk membantu sesama yang membutuhkan dan juga dengan begitu masyarakat lebih merasa dekat dengan Lifebuoy dan mengingat identitas dari brand itu sendiri.

Kampanye IMC dengan produk kemasan khusus berkaitan erat dengan interaksionisme simbolis, dimana program ini juga meningkatkan makna pada seorang individu ketika pelanggan melihat kemasan tersebut. Menyadarkan pelanggan akan pentingnya upaya-upaya untuk membantu sesama yang masih memiliki keterbatasan di luar sana. Sebagai seorang individu yang selalu berinteraksi dengan orang lain, hal ini sangat berkaitan erat dengan rasa simpati dan empati terhadap orang lain dimana jika kita dapat menyalurkan rasa yang muncul tersebut maka akan ada makna pada individu yang mengalaminya tersebut.

Lalu secara publikasi oleh media massa, program yang diadakan oleh Lifebuoy ini akan menjangkau banyak khalayak dari seluruh Indonesia. Hal ini dikarenakan produk Lifebuoy banyak digunakan oleh keluarga-keluarga di Indonesia dan juga selain banyaknya khalayak namun juga adanya pesan yang secara jelas diberikan melalui produk Lifebuoy yaitu untuk senantiasa mencuci tangan menggunakan sabun agar terbebas dari kuman penyakit, dan juga 
bahwa masih banyak anak-anak yang memerlukan edukasi mencuci tangan di sekolah-sekolah mereka. Membantu sesama dapat dimulai dari hal kecil dan dimulai dari diri kita sendiri.

\section{$\underline{\text { Spesifik }}$}

Penggemar orkestra berasal dari kalangan tertentu dan beragam, sama seperti segmen khalayak yang dituju perusahaan untuk memasarkan produk di wilayah atau area tertentu. Preferensi konsumen dapat disegmentasikan ke dalam sejumlah kategori, seperti: gaya hidup, motivasi pembelian, dan perbedaan demographic. Kategorisasi atas tingkat preferensi mengikuti segmentasi pasar mengarahkan perusahaan pada analisis terstruktur mengenai perbedaan cara yang dalam pengambilan keputusan terhadap pembelian, atau cara konsumen melakukan seleksi terhadap suatu barang yang mengarah kepada sebuah produk atau merek yang ideal (produk atau merek yang dapat memenuhi harapan konsumen dengan "tepat) (Soemanagara, 2012: 20).

Organisasi mengumpulkan informasi tentang pelanggan dengan tujuan untuk meningkatkan komunikasi sebagai upaya dari meningkatkan kesadaran pelanggan dan menarik calon pelanggan (Thorson and More dalam Mudzanani, 2015: 93).

Lifebuoy, salah satu merek sabun tertua yang sudah mendunia, yang pertama kalinya diluncurkan pada tahun 1894. Lifebuoy dengan produk yang dipercaya dapat memberikan kebersihan secara maksimal untuk tubuh yang dapat melindungi badan dari kuman yang berasal dari lingkungan sekitar.
Lifebuoy diciptakan untuk semua wilayah yang ada di Indonesia, namun segmen khalayak yang dipilih oleh produk Lifebuoy memang ditujukan untuk keluarga yang menginginkan kebersihan secara maksimal untuk semua anggota keluarga pembelinya. Karena produk Lifebuoy yang memiliki segmentasi khalayak secara spesifik, yaitu lebih ditujukan kepada keluarga, maka dari segi pemilihan brand ambassador dan bintang iklan yang dipilih juga merupakan keluarga utuh, salah satunya yaitu Keluarga Christian Sugiono dan Titi Kamal yang merupakan dari keluarga kalangan artis.

Dalam penayangan iklan Lifebuoy yang mereka tampilkan, memaparkan bahwa anak kecil yang cenderung beraktivitas dan suka bermain diluar ruangan akan rentan dan cepat terjankit kuman yang menjadi serangan penyakit bagi si anak. Dengan begitu keluarga harus mengantisipasi dalam menjaga perlindungan tubuh si anak dari kuman akibat bermain dan beraktivias di luar ruangan.

Hal kecil yang diajarkan dari Lifebuoy, yaitu kebersihan yang diawali dengan rajin mencuci tangan menggunakan sabun. Khususnya bagi anak-anak yang banyak beraktivitas diluar ruangan. Keluarga harus lebih waspada dan memperhatikan setiap aktivitas yang dilakukan si anak. Sebelum memasukan makanan ke dalam mulut, sebaiknya mencuci tangan menggunakan sabun terlebih dahulu. Karena kuman yang tidak terlihat pada tangan, akan tertelan dan menjadi pemicu timbulnya penyakit bagi tubuh si anak.

Dengan adanya promosi "Cuci Tangan menggunakan Sabun" yang sudah banyak tersebar 
di wilayah Indonesia, melalui iklan maupun kampanye yang dibuat secara langsung mampu menarik perhatian khalayak luas, terutama menarik perhatian kalangan orang tua untuk memberikan arahan kepada anak-anaknya agar lebih rajin mencuci tangan menggunakan sabun.

\section{$\underline{\text { Keterpaduan }}$}

Dalam orkestrasi musik, sikap tidak menonjolkan diri dan rendah hati sangat terasa di antara para pemain orkestra agar menciptakan keterpaduan musik yang berirama dan tertanam dibenak pendengarnya. Di dalam IMC, bila menyatukan kreatifitas dalam program yang dijalankan akan terjadi sinergi komunikasi pemasaran yang kuat. Agar dapat terus memberikan perlindungan kesehatan dan pengalaman mencuci yang tidak hanya menyehatkan tapi juga menyenangkan bagi konsumennya. Lifebuoy terus-menerus melakukan berbagai macam inovasi produk.

Meskipun Lifebuoy mempromosikan dua jenis produk dalam waktu berdekatan, produk yang dipromosikan tersebut merupakan dua jenis produk yang berbeda. Iklan tersebut memuat sampo Lifebuoy varian sampo sudah dikenal secara luas oleh publik dengan sabun Lifebuoy dengan varian aroma terbarunya.

\begin{tabular}{|l|l|l|}
\hline Kategori & \multicolumn{1}{|c|}{ Varian } & \multicolumn{1}{|c|}{ Manfaat } \\
\hline \multirow{5}{*}{ Sampo } & $\begin{array}{l}\text { Strong } \\
\text { Shiny } \\
\text { (Hijau) }\end{array}$ & $\begin{array}{l}\text { Merawat rambut agar } \\
\text { senantiasa sehat dan } \\
\text { menjadikannya 10x lebih } \\
\text { kuat }\end{array}$ \\
\cline { 2 - 4 } & $\begin{array}{l}\text { Anti- } \\
\text { Dandruff } \\
\text { (Biru) }\end{array}$ & $\begin{array}{l}\text { Membantu menjaga } \\
\text { kesehatan rambut, tak ada } \\
\text { ketombe dan mengatasinya } \\
\text { datang kembali }\end{array}$ \\
\cline { 2 - 4 } & $\begin{array}{l}\text { Anti-Hair } \\
\text { Fall (Merah) } \\
\text { dan membantu mengurangi } \\
\text { kerontokan hingga 95\% }\end{array}$ \\
\hline Hand & Lemon & Menjaga tangan anda \\
\hline
\end{tabular}

\begin{tabular}{|c|c|c|}
\hline \multirow[t]{3}{*}{ Sanitizer } & $\begin{array}{l}\text { Fresh } \\
\text { (Kuning) }\end{array}$ & $\begin{array}{l}\text { terlindungi dari } \text { kuman } \\
\text { hingga } 10 \text { jam sepanjang } \\
\text { hari, sekaligus menjadikan } \\
\text { tangan anda segar dengan } \\
\text { wangi lemon }\end{array}$ \\
\hline & $\begin{array}{ll}\text { Hand } & \\
\text { Sanitizer } & \\
\text { Total } & 10 \\
\text { (Merah) } & \end{array}$ & $\begin{array}{l}\text { Menjaga tangan } \quad \text { anda } \\
\text { terlindungi dari kuman } \\
\text { hingga } 10 \text { jam sepanjang hari }\end{array}$ \\
\hline & Care (Biru) & 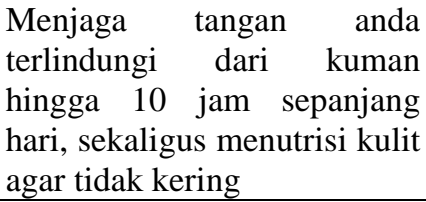 \\
\hline \multirow{3}{*}{$\begin{array}{l}\text { Sabun } \\
\text { Cuci } \\
\text { Tangan }\end{array}$} & $\begin{array}{l}\text { Cool Fresh } \\
\text { (Biru Muda) }\end{array}$ & $\begin{array}{l}\text { Melindungi dari } 10 \text { infeksi } \\
\text { kulit yang disebabkan oleh } \\
\text { kuman dan membantu anda } \\
\text { merasa sejuk dan segar }\end{array}$ \\
\hline & $\begin{array}{l}\text { Mild Care } \\
\text { (Biru) }\end{array}$ & $\begin{array}{l}\text { Menjaga kehalusan kulit } \\
\text { sekaligus melindungi dari } 10 \\
\text { infeksi kulit oleh kuman }\end{array}$ \\
\hline & $\begin{array}{l}\text { Total10 } \\
\text { (Merah) }\end{array}$ & $\begin{array}{l}\text { Memberikan perlindungan } \\
\text { secara total dan menyeluruh } \\
\text { pada kulit }\end{array}$ \\
\hline \multirow{4}{*}{$\begin{array}{l}\text { Sabun } \\
\text { Mandi }\end{array}$} & $\begin{array}{l}\text { Nature Pure } \\
\text { (Hijau) }\end{array}$ & $\begin{array}{ll}\text { Membersihkan } & \text { pori-pori } \\
\text { secara mendalam } & \end{array}$ \\
\hline & $\begin{array}{l}\text { Matcha } \\
\text { (Hijau) }\end{array}$ & $\begin{array}{l}\text { Membantu melawan masalah } \\
\text { kesehatan kulit seperti gatal- } \\
\text { gatal dan kemerahan karena } \\
\text { kuman }\end{array}$ \\
\hline & $\begin{array}{l}\text { Kasturi } \\
\text { Musk } \\
\text { (Cokelat) }\end{array}$ & $\begin{array}{l}\text { Memberikan perlindungan } \\
\text { terhadap kuman penyebab } \\
\text { masalah kesehatan dengan } \\
\text { wewangian yang istimewa }\end{array}$ \\
\hline & $\begin{array}{l}\text { Charcoal } \\
\text { (Hitam) }\end{array}$ & $\begin{array}{l}\text { Membantu melawan masalah } \\
\text { kesehatan kulit seperti gatal- } \\
\text { gatal dan kemerahan karena } \\
\text { kuman }\end{array}$ \\
\hline
\end{tabular}

Sumber : Lifebuoy

\section{Tabel 1 Jenis-jenis Produk Lifebuoy}

Lifebouy memiliki banyak produk dengan varian yang berbeda, selain sabun batang dan sabun cair untuk merawat kulit dan terlindung dari kuman mereka juga mengeluarkan sampo yang cocok untuk seluruh anggota keluarga yang ingin tetap menginginkan tampil dengan rambut yang sehat, bersih dan nyaman yaitu Lifebuoy Sampo Strong \& Shiny dengan Milk Protein Lock Formula agar rambut kuat dan berkilau. Tidak hanya itu, namun varian lain dapat mengatasi ketombe dan rambut rontok. 
Strategi ini dilakukan seiring dengan visi dari Lifebouy, yaitu "Kami bekerja untuk menciptakan masa depan yang lebih baik setiap hari dan kami membantu konsumen merasa nyaman, berpenampilan baik dan lebih menikmati hidup melalui brand dan layanan yang baik bagi mereka dan orang lain”. Oleh karena itu, Lifebouy berusaha menghadirkan berbagai produk yang efektif untuk menjaga kebersihan kulit.

Iklan yang ditampilkan dari berbagai produk Lifebouy terpisah, karena diharapkan konsumen dapat memberikan apresiasi kepada publik mengenai makna iklan, serta memberikan masukan kepada masyarakat tentang iklan karena tujuan iklan adalah untuk mempersuasi, sehingga diharapkan pandangan mereka semakin objektif dan lebih fokus terhadap produk produk dari lifebouy.

\section{$\underline{\text { Apresiasi }}$}

Apresiasi dalam pergelaran musik merupakan ucapan terima kasih konduktor sebagai bentuk respon dan partisipasi dari penonton yang telah datang dan menikmati acara. Dalam IMC, perusahaan juga memiliki program customer rewards atau bagi-bagi hadiah kepada pelanggan setianya sebagai bentuk penghargaan atas loyalitas terhadap perusahaan.

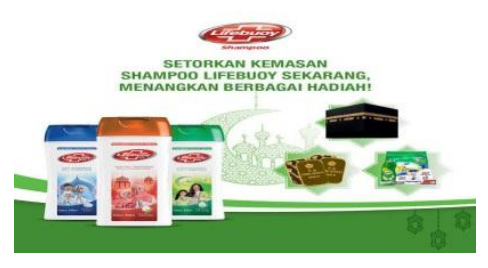

Sumber : Lifebuoy

\section{Gambar 5 Poster Lifebuoy Sampo Edisi Ramadhan Berkah}

Pada tahun 2019, Lifebuoy bersama dengan Waste4Change mengadakan kegiatan bagi-bagi hadiah berupa paket umroh bagi pelanggan setianya untuk menyambut bulan suci Ramadhan.

Sehingga, Lifebuoy mengadakan customer rewards "Lifebuoy Sampo Edisi Ramadhan Berkah" dengan mengumpulkan kemasan Lifebuoy Sampo dan mendapatkan poin untuk memenangkan paket umroh, emas dan juga hampers Unilever.

Dengan adanya customer rewards tersebut, Lifebuoy secara tidak langsung mengajak semua pelanggannya untuk melakukan demi lingkungan yaitu memilah sampah daur ulang kemasan Lifebuoy Sampo. Kegiatan ini tentunya membangun citra positif Lifebuoy dari segala aspek dan segala pihak baik dari kalangan pelanggan setia, mitra bisnis bahkan bukan pelanggan. Pesan yang disampaikan oleh Lifebuoy termasuk pesan tersirat dimana melalui kegiatan tersebut ternyata mampu membawa dampak positif terhadap berkurangnya sedikit sampah plastik di lingkungan sekitar. Sehingga bukan hanya pelanggan Lifebuoy yang merasakan dampak positif dari kegiatan tersebut melainkan semua orang yang berada di sekitar lingkungan tersebut juga merasakan dampaknya.

Kegiatan ini tentunya meningkatkan brand awareness dan juga interaksi antara Lifebuoy dengan pelanggannya. Lifebuoy secara konsisten berinteraksi dengan pelanggannya melalui kegiatan-kegiatan yang sejalan dengan tujuannya yaitu menciptakan kehidupan yang bersih, ramah dan mendukung kehidupan melalui perlindungan terbaik. 


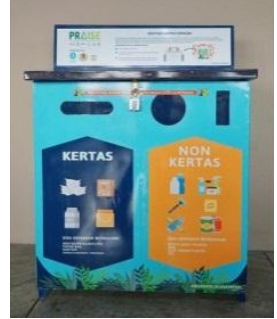

Sumber : Unilever

\section{Gambar 6 PRAISE Dropping Box}

Kegiatan ini sendiri di publikasikan oleh Lifebuoy melalui website Unilever mengenai sustainable living prakarsa keberlanjutan di bidang lingkungan "PRAISE Dropping Box". "PRAISE" merupakan kepanjangan dari Packaging and Recycling Association for Indonesia Sustainable Environment. Kegiatan tersebut tentunya bertujuan mengedukasi sekaligus membentuk kebiasaan masyarakat untuk memilah sampah demi mendukung usaha daur ulang sampah kemasan secara berkelanjutan.

\section{SIMPULAN}

Kampanye dan kegiatan pemasaran dari Lifebuoy merupakan wujud nyata dari penerapan terminologi Intergrated Marketing Communication “Orchestration”. Secara selaras Lifebuoy mengadakan setiap kampanye dan kegiatan pemasarannya sejalan dengan tujuan mulianya. Kegiatan pemasaran Lifebuoy merupakan konstruksi simbolis dari pengiklanan mengenai pentingnya menjaga kebersihan dan kesehatan diri sejak dini. Kebiasaan dan disiplin diri untuk hidup bersih yang tampak sederhana itu sebenarnya sangat mendasar, karena kebersihan adalah pangkal kesehatan dan berdampak pada sikap dan perilaku keseharian menjadi lebih baik.
Interaksi sosial yang dibangun oleh Lifebuoy pada akhirnya menjadikannya sebagai top of mind di masyarakat sebagai sabun cuci tangan terbaik. Tidak melulu mengiklankan tentang produknya, tetapi Lifebuoy berfokus pada usaha membentuk kebiasaan menjaga kebersihan diri dan berkomitmen meningkatkan kehidupan berkelanjutan sehingga orang tidak lagi merasa khawatir terhadap kebersihan dan akibatnya buruknya. Lifebuoy juga senantiasa memberikan edukasi-edukasi khususnya kepada para ibu yang sangat berperan dalam mendidik anak-anak sejak dini. Anak-anak sangat perlu untuk diajarkan bagaimana cara hidup sehat dan bersih mulai dari lingkungan terkecil yaitu keluarga. Selain dari keluarga, sekolah juga dapat menjadi sarana terpenting bagi anak sehingga Lifebuoy selalu bekerja sama dengan pemerintah untuk memberikan program-program edukasi di sekolahsekolah agar tidak hanya saja menjual produk namun memberikan nilai yang penting bagi masyarakat. Pesan dan interaksi yang baik menunjang terpeliharanya hubungan antara pelanggan dan stakeholder sehingga menciptakan hubungan dan citra yang positif serta menguntungkan bagi Lifebuoy.

\begin{tabular}{|l|l|}
\hline Elemen Orkestrasi & \multicolumn{1}{|c|}{ Implementasi Lifebuoy } \\
\hline \multirow{2}{*}{ Satu Dirijen } & $\begin{array}{l}\text { Mempunyai beberapa kategori } \\
\text { produk dimana masing-masing } \\
\text { produk mempunyai manfaat yang } \\
\text { sama yaitu membersihkan dan } \\
\text { mengurangi kuman yang ada di } \\
\text { kulit, tangan badan maupun kulit } \\
\text { kepala. }\end{array}$ \\
\hline Harmonisasi & $\begin{array}{l}\text { Melakukan kampanye-kampanye } \\
\text { sejalan dengan tujuan mulianya, } \\
\text { contoh kampanye "5 Tahun Bisa } \\
\text { untuk NTT" }\end{array}$ \\
\hline Tematik & $\begin{array}{l}\text { Mengadakan kegiatan Cuci } \\
\text { Tangan Pakai Sabun ke sekolah- }\end{array}$ \\
\hline
\end{tabular}




\begin{tabular}{|l|l|}
\hline \multirow{3}{*}{ Berirama } & $\begin{array}{l}\text { sekolah guna memperingati Hari } \\
\text { Cuci Tangan Sedunia }\end{array}$ \\
\hline Spesifik & $\begin{array}{l}\text { Meluncurkan produk sabun cuci } \\
\text { tangan dengan kemasan khusus } \\
\text { yang bertuliskan "Gabung Aksi } \\
\text { Indonesia Merdeka dari Kuman" }\end{array}$ \\
\hline \multirow{5}{*}{ Keterpaduan } & $\begin{array}{l}\text { Lifebuoy memiliki segmentasi } \\
\text { khalayak secara spesifik, yaitu } \\
\text { lebih ditujukan kepada keluarga }\end{array}$ \\
\hline $\begin{array}{l}\text { Mempromosikan dua jenis produk } \\
\text { dalam waktu berdekatan, produk } \\
\text { yang dipromosikan tersebut } \\
\text { merupakan dua jenis produk yang } \\
\text { berbeda. Iklan tersebut memuat } \\
\text { sampo Lifebuoy varian sampo } \\
\text { sudah dikenal secara luas oleh } \\
\text { publik dengan sabun Lifebuoy } \\
\text { dengan varian aroma terbarunya. }\end{array}$ \\
$\begin{array}{l}\text { Mengadakan kegiatan bagi-bagi } \\
\text { hadiah berupa paket umroh, } \\
\text { "Lifebuoy Sampo Edisi Ramadhan } \\
\text { Berkah" bersama Waste4Change } \\
\text { bagi pelanggan setianya untuk } \\
\text { menyambut bulan suci Ramadhan. }\end{array}$ \\
\hline \multirow{3}{*}{ Apresiasi }
\end{tabular}

\section{Tabel 2 Implementasi Lifebuoy terhadap Elemen Orkestrasi}

Lifebuoy menanam citra dirinya sebagai perusahaan yang peduli terhadap problema di tengah-tengah masyarakat. Salah satu program Lifebuoy yang bukan hanya mempromosikan produknya tetapi turut berperan membantu mengatasi masalah sosial di Indonesia melalui Lifebuoy Berbagi Sehat (LBS). Pesan-pesan yang memang masih terkait dengan manfaat produk untuk menjaga kebersihan, namun gerakan moral dan aksi nyata yang digulirkan berdampak positif untuk kesehatan masyarakat luas.

Pemasaran produk melalui iklan di televisi, diklaim juga efektif untuk memberikan edukasi kepada masyarakat, dimana setiap iklan Lifebouy lebih menampilkan sosok seorang ibu yang sedang mengajarkan anak-anaknya untuk hidup sehat dengan mandi maupun cuci tangan menggunakan sabun setelah beraktivitas di luar rumah. Keselarasan setiap program-program yang dicanangkan oleh Lifebuoy memiliki dampak serta peran yang sangat besar dalam menunjang keberlangsungan Lifebuoy dalam kehidupan masyarakat. Adanya keseimbangan antara pemasaran maupun kontribusi nilai yang diberikan oleh Lifebuoy bagi para konsumen tentunya sangat bernilai dan bermanfaat bagi masyarakat Indonesia maupun dunia.

Lifebouy membentuk loyalitas konsumen dari reputasi merek induk yang telah dikenal konsumen memiliki kualitas terbaik, harga yang sesuai serta mampu memberikan manfaat yang sesuai dengan harapan konsumen. Pengalaman yang baik dengan suatu merek akan memberikan kepuasan yang besar bagi konsumen yang kemudian akan menarik minat konsumen untuk tetap memakai bahkan merekomendasikan produk tersebut kepada orang lain dan akan beralih ke tingkat loyal.

\section{DAFTAR PUSTAKA}

Ahmadi, D. (2008). Interaksi Simbolik: Suatu Pengantar. Mediator: Jurnal Komunikasi, 9(2), 301-316. https://doi.org/10.29313/mediator.v9i2.1115

Bandur, A. (2019). Penelitian Kualitatif: Studi MultiDisiplin Keilmuan Nvivo 12 Plus. Mitra Wacana Media.

Bani, B., Komunitas, A., Bhakti, D., Susanto, D., Komunitas, A., \& Bhakti, D. (2019). PENGARUH KOMUNIKASI PEMASARAN DAN MOTIVASI. Jurnal Ekonomi Dan Manajemen STIE Pertiba Pangkalpinang, 5(1), 12-21.

Depoktren. (2014). Cara Mencuci Tangan yang Benar. Depoktren.

https://www.depoktren.com/2014/10/20/caramencuci-tangan-yang-benar/, diakses pada 16 Februari 2020

Halik, A. (2013). Buku Daras Uin Alauddin Komunikasi Massa Universitas Islam Negeri (Uin). $\quad$ http://repositori.uinalauddin.ac.id/338/1/Komunikasi Massa full.pdf 
Huda, N. (2014). Pengaruh Integrated Marketing Communication Terhadap Keputusan Konsumen Dalam Membeli Mobil Merek Honda Jazz Pada pt. Arista auto Prima Cabang Pekanbaru. Journal of Chemical Information and Modeling, 1(2), 111.

https://doi.org/10.1017/CBO9781107415324.004

Hutapea, E. (2016). Identifikasi Diri Melalui SimbolSimbol Komunikasi (Studi Interaksionisme Simbolik Komunitas Pemakai Narkoba Di DKI Jakarta). Jurnal Bricolage, 2(1), 1-14.

Imran, H. A. (2012). Media Massa, Khalayak Media, The Audience Theory, Efek Isi Media dan Fenomena Diskursif. Jurnal Studi Komunikasi Dan Media, 16(1), 47-60. https://doi.org/10.31445/jskm.2012.160103

Kartini. (2017). Cuci Tangan Pakai Sabun Cegah Penyakit Menular. Majalah Kartini. http://majalahkartini.co.id/berita/cuci-tanganpakai-sabun-cegah-penyakit-menular/, diakses pada 16 Februari 2020

Kholik, I. (2015). Bingkai Berita Media Indonesia Tentang Terpilihnya Susilo Bambang Yudhoyono Sebagai Ketua Umum Partai Demokrat (Analisis Framing Pada Pemberitaan Media Indonesia). Bricolage, 1(2).

Krypton, A. (2018). Strategi Peningkatan Brand Awareness Mobile Ticketing Apps melalui Metode Integrated Marketing Communication. Jurnal Sosial Humaniora Terapan, 1(1), 41-50.

Lestari, S. P. (2015). Hubungan Komunikasi Pemasaran Dan Promosi Dengan Keputusan Memilih Jasa Layanan Kesehatan (Studi Pada Rumah Sakit Islam Lumajang). Jurnal Interakasi, 4(2), 139-147.

Lifebuoy. (2019). Lifebuoy Shampoo. Facebook. https://www.facebook.com/LifebuoyShampoo/po sts, diakses pada 16 Februari 2020

Lifebuoy. (2020). Lifebuoy. Lifebuoy. https://www.lifebuoy.co.id, diakses pada 30 Januari 2020

Liputan6. (2013). Iklan Lifebuoy 5 Tahun Bisa untuk NTT Sudah Tak Tayang Lagi. Liputan6. https://www.liputan6.com/health/read/762580/ikl an-lifebuoy-5-tahun-bisa-untuk-ntt-sudah-taktayang-lagi, 16 Februari 2020

Lokadata. (2018). Cuci tangan tingkatkan kualitas hidup masyarakat. Lokadata. https://lokadata.id/artikel/cuci-tangan-tingkatkankualitas-hidup-masyarakat, diakses pada 16 Februari 2020

Mahayoni. (2015). Menata Komunikasi Pada Media Sosial Online Untukmenghindari Jerat Hukum. Bricolage, 1(2). https://doi.org/10.1017/CBO9781107415324.004

Morissan. (2013). Teori Komunikasi. Ghalia Indonesia.
Mudzanani, T. (2015). A review and analysis of the role of integrated marketing communication message typology in the development of communication strategies. African Journal of Marketing Management, 7(8), 90-97. https://doi.org/10.5897/ajmm2015.0475

Nurhadi, Z. F. (2015). Teori Teori Komunikasi Dalam Perspektif Kualitatif. Ghalia Indonesia.

Pfefferman, N., Minshall, T., \& Mortara, L. (2013). Strategy and Communication for Innovation (2nd ed.). Springer. https://doi.org/10.1007/978-3-64241479-4

Putra, R. P. K., \& Nurfebiaraning, S. (2017). KONSEP DIRI PENGGUNA SNAPCHAT The Self Concept of Snapchat Users (A Phenomenology Study to Active Students of Communication Department in Telkom University). E-Proceeding of Management, 4(1), 1044-1049. http://isparmo.web.id

Siregar, N. S. S. (2011). Kajian tentang Interaksionisme Simbolik. Jurnal Ilmu SosialFakultas Isipol UMA, 4(2), 100-110. http://ojs.uma.ac.id/index.php/perspektif/article/v iew/86

Suherman, A. (2019). Strategi Marketing Politik Anggota Legislatif Perempuan Marketing Policy Strategy for Members of Legislative Women in the 2014 Election in the City of. Medialog: Jurnal Ilmu Komunikasi, 2(36), 11-21.

Tarsani. (2016). Strategi Komunikasi Pemasaran Dompet Dhuafa dalam Meningkatkan Kepercayaan Muzakki. Jurnal Bricolage, 2(1), 56-70.

Tuhuteru, A., \& Sukmawati, L. (2019). Strategi Komunikasi Pemasaran ( Suatu Perencanaan Komunikasi Pemasaran pada PT . Quipper Edukasi Indonesia ). Medialog: Jurnal Ilmu Komunikasi, 2(2), 62-68.

Ulfa, R., \& Marta, R. F. (2016). IMPLEMENTASI KOMUNIKASI PEMASARAN TERPADU PADA YAYASAN NURUL IBAD JAKARTA TIMUR. Jurnal Bricolage, 2(2), 71-81.

Unilever. (2020). No Title. Unilever Indonesia. https://www.unilever.co.id/about/, diakses pada 30 Januari 2020

Widoawati, D. (2012). Efek Media Massa Terhadap Khalayak. Jurnal Adzikra, 3(1), 75-98. https://doi.org/10.1017/CBO9781107415324.004 